\title{
VIOLENCE AND THE LAW \\ in Gianrico CAROFIGLIO's Literary COURTROOM
}

\section{ELENA Past}

\begin{abstract}
Summary: Gianrico Carofiglio's novels featuring attorney-protagonist Guido Guerrieri have gained popularity in Italy and abroad since the first in the series emerged in 2002. Although often discussed alongside other popular crime fiction, Carofiglio's work also has a wider resonance, participating in debates about justice, violence, and the law. This article proposes connections between the Guerrieri novels and several contemporary discussions of state violence-including essays by Jacques Derrida, Dominick La Capra, and Giorgio Agamben-that gravitate around Walter Benjamin's essay, "Critique of Violence." Carofiglio's novels, like these essays, lead us to contemplate the question of what action is possible once law's violence has been acknowledged.
\end{abstract}

In Testimone inconsapevole (2002), Gianrico Carofiglio's first novel, protagonist Guido Guerrieri recounts that as a child he wanted to be a sheriff, like Gary Cooper's lawman Will Kane in High Noon: "Quando mi dicevano che in Italia non esistono gli sceriffi, ma tutt'al più i poliziotti, rispondevo con prontezza. Sarei stato un poliziotto sceriffo. Ero un bambino duttile e volevo dare la caccia ai cattivi, in un modo o nell'altro" (220). And yet Guerrieri hazily remembers seeing, at the age of eight or nine, a pursesnatcher arrested and savagely beaten by two police officers who shouted expletives in pugliese. The scene was forever impressed on the mind of the young boy: violent language and physical violence at the hands of the "enforcers of the law" led him to renounce his desire to be its representative, at least in the capacity of police officer. "Qualche volta," says Guerrieri, "mi ero detto che avevo fatto l'avvocato per una specie di reazione al disgusto di quella scena" (222). As if having learned the lesson of Leonardo Sciasciass policemen (Bellodi in Il giorno della civetta, Lagandara in Una storia semplice, the Vice in Il cavaliere e la morte) who hope to become or regret not having become attorneys, Guerrieri seems to figure himself as a servant of what Sciascia called the "legge in assoluto," an abstract, universal justice. ${ }^{1}$

${ }^{1}$ A number of Sciascia's police investigators began their careers with the desire or the intention to be lawyers: impartial representatives of the law, and not its 
Carofiglio, an anti-mafia prosecutor from Bari and more recently a member of the Italian Senate, is author of a series of novels, often described as legal procedurals or crime thrillers, that follow the professional and personal adventures of the fretful attorney Guerrieri. ${ }^{2}$ Since his 2002 debut, Carofiglio has rapidly become one of the best-known writers of crime fiction in Italy. For example, the third of the Guerrieri novels, Ragionevoli dubbi (2006), was included in a 2008 collection of works by "undici scrittori di grosso calibro" selected by La Repubblica and L'Espresso for a summer promotion. Carofiglio's name appeared alongside those of Carlo Lucarelli, Andrea Camilleri, Carlo Fruttero, Loriano Macchiavelli, and Giorgio Scerbanenco, among others, marking his inclusion in the canon of popular crime fiction that in recent years has witnessed enormous growth. In interviews, however, Carofiglio resists this classification as writer of genre fiction, preferring the idea that his works have more universal appeal. ${ }^{3}$

My purpose in this article is not to contest Carofiglio's generic classification. Rather, I aim to show that his work resonates powerfully in contemporary debates about justice, violence, and the law. In the aforementioned anecdote, as Guerrieri contemplates his career, he concludes that he decided to become an attorney for lack of a better idea, "perché non avevo trovato di meglio o perché non ero stato capace di cercarlo" (Testimone 222). Yet a sense of discomfort and disgust at the exigency of applying the

enforcers. In Una storia semplice, the initially optimistic Lagandara actively pursues his degree: "Si era iscritto alla facoltà di legge, la frequentava quando e come poteva, studiava. La laurea in legge era la suprema ambizione della sua vita, il suo sogno" (40). Bellodi in Il giorno della civetta was "destined" to be an attorney (30). And in Il cavaliere e la morte, the Vice explains that he did not choose to be a lawyer "Forse perché mi sono illuso che si potesse essere avvocati appunto facendo i poliziotti [...]' " (82). Sciascia uses the term "legge in assoluto" to describe the qualities of the canonical detective, a status his protagonists never achieve because of the corrupt world in which they live: "Lincorruttibilità $\mathrm{e}$ infallibilità dell'investigatore, la sua quasi ascetica vita [...], il fatto che non rappresenta la legge ufficiale ma la legge in assoluto, la sua capacità di leggere il delitto nel cuore umano oltre che nelle cose, cioè negli indizi, e di presentirlo, lo investono di luce metafisica, ne fanno un eletto" (Opere 1183).

2 This article discusses three novels, Testimone inconsapevole (2002), Ad occhi chiusi (2003), and Ragionevoli dubbi (2006). A fourth novel featuring attorney Guerrieri, Le perfezioni provvisorie (2010), has just been published by Sellerio.

3 In an interview in Panorama, Carofiglio quotes G.K. Chesterton as he argues that "la distinzione fondamentale è tra libri scritti bene oppure male." He insists, "Io rifuggo da ogni intento didascalico; mi interessa solo raccontare storie appassionanti" (Barbolini 151). 
force of law motivates Guerrieri's career and Carofiglio's fiction. The attorney's hesitant account of the path that led him to become a lawyer makes evident his awareness of the ethical complexity of such a choice. As the contemplative Guerrieri reflects on his profession over the course of the novels, he proceeds through a meditation on the role of the justice system and its impact on individuals. Carofiglio's work examines the undercurrent of violence that - in his view- underlies the system and risks undermining its purpose. His works exhibit the conviction that legal channels should be followed in order to exercise justice, but they betray a constant fear that justice is too often misapplied. Carofiglio's novels, like those by Sciascia, weigh in on matters of civil rights, discrimination, and mafia, contesting abuses of power. Like Sciascia, he lacks intellectual confidence in the potential for an absolute law, able to do good. Yet in a more hopeful key than anything found in Sciascia's fiction, his attorney-protagonist provisionally succeeds in using pragmatic strategies - and especially discursive ones-to distance his clients from the judicial system, and from the violence that seems to be an inherent part of it.

\section{Violence and the Law}

The motivating philosophy for Carofiglio's fiction and the practical basis for his work is evident at the end of a legal essay he wrote titled L'arte del dubbio. ${ }^{4} \mathrm{He}$ ends the work with a quote by Norberto Bobbio from a volume on rhetoric:

La teoria dell'argomentazione rifiuta le antitesi troppo nette: mostra che tra la verità assoluta degli invasati e la non-verità degli scettici c'è posto per le verità da sottoporsi a continua revisione mercé la tecnica di addurre ragioni pro e contro. Sa che quando gli uomini cessano di credere alle buone ragioni, comincia la violenza. (Arte 222, my emphasis)

Argumentation and rhetoric, two discursive strategies and essentially

4 Carofiglio's interest in theorizing the legal system began before his career as a novelist, and is made explicit in his revision of this legal manual on cross-examination, published for his fiction-reading fans in 2007. A work originally published by Giuffrè as a manual for attorneys under the title Il controesame. Dalle prassi operative al modello teorico (1997), L'arte del dubbio stands at the crossroads of fiction and the law. For the popular republication of this earlier work, Carofiglio eliminated sections dedicated to juridical practice and simplified (or worked to "bonificare," "reclaim" or "rehabilitate") its language, but maintains that the substance remains unchanged (Arte 12). 
the subject of L'arte del dubbio, keep violence at bay. Words, according to Bobbio, and more specifically "buone ragioni," are correctives both to excessively absolutist forms of thinking — the "antitesi troppo nette" - and to physical violence. The attorney, whose job is rooted in manipulation of discourse, becomes the representative of the law best positioned to adopt this theory of argumentation, able to harness the power of stories so that he or she may counter the danger of violence. My contention is that Carofiglio's work recognizes the perilous contradictions of enforcing the law, and that his novels revolve around the question of what to do when law's violence has been acknowledged. Guerrieri often attempts to skirt the law, seeking acquittals and finding ways to distance his clients from its more physically violent applications. Yet as he practices his career, the attorney falls victim to the violent paradox of the law, using aggressive language in the courtroom and, occasionally, forceful action on the streets. Violent language and violent action, recurrent themes in the Guerrieri novels, lead the attorney to a pathological relationship with his career, a pathology which manifests itself in physical illness. By casting a hesitant, sometimes-problematic participant in the legal system as central protagonist, Carofiglio maintains an engaged curiosity regarding how to respond to the apparently inevitable presence of violence in the law.

The question of the relationship between violence, the law, and justice is one that Walter Benjamin contemplates in his brilliant, much-discussed essay "Zur Kritik der Gewalt," translated in English as "Critique of Violence." Jacques Derrida, who has written extensively about this work, calls it "brief and disconcerting" (Derrida 29). Benjamin's complex work helps to focus some of the most pressing questions in Carofiglio's fiction. According to Benjamin:

the function of violence in lawmaking is twofold, in the sense that lawmaking pursues as its end, with violence as the means, what is to be established as law, but at the moment of instatement does not dismiss violence; rather, at this very moment of lawmaking, it specifically establishes as law not an end unalloyed by violence, but one necessarily and intimately bound to it, under the title of power. (295)

Law and violence are thus inextricably intertwined, as violence represents both the means of establishing law (by way of revolution, for exam-

5 In the specific case of the police, the philosopher asserts that intervention on the part of law-enforcement officers signals the point "at which the state [...] can no longer guarantee through the legal system the empirical ends that it desires at 
ple), and the means of preserving it once established. 5 As Derrida points out, the complication regarding the nature of violence resides in the translation of the term "Gewalt" as "violence," for Gewalt is "both violence and legitimate power, justified authority" (Derrida 6). This troubling indeterminate space between legitimate authority and violence, which seems to result in the omnipresence of violence in the application of the law, weighs heavily on Guerrieri. Witnessing the brutality of the two police officers, a foundational event for the attorney, becomes the base from which Guerrieri launches a convoluted and sceptical relationship with the legal system as expressed in the courts. The excessive force of the police officers, who punch and kick the young thief until he is unable to breathe, comes to represent the suffocating weight of a formless power. Benjamin describes this power as a "nowhere tangible, all-pervasive, ghostly presence in the life of civilized states," a power which, in a democracy, "bears witness to the greatest conceivable degeneration of violence" (287).

Benjamin's essay, composed in 1921, has in the past several decades become central to discussions of philosophy and political theory. Amongst the most prominent of these scholarly reactions, Derrida and Dominick La Capra have debated Benjamin's essay in articles in the Cardozo Law Review (1989 and 1990),6 and Giorgio Agamben focuses on "Critique of Violence" in State of Exception (2003). Why the return to Benjamin? All of these more contemporary discussions share with Benjamin's essay a conviction that law and violence are entangled, that some kind of justice might exist outside of these two, and that it is worthwhile to attempt to imagine how or where this justice might reside. 7 Though they take issue with the controversial ending of Benjamin's essay, in which the experience of justice

any price to attain" (287). Benjamin also asserts that law attempts to monopolize the violence that individuals might exercise- that is to say, to prohibit individuals from using violence-not in order to preserve legal ends, but simply to preserve the law itself (281).

6 Derrida's work, "Force of Law," was originally presented at a symposium titled Deconstruction and the Possibility of Justice at the Cardozo School of Law in 1989, and then published in the Cardozo Law Review. My citations come from a 1992 volume collecting papers from the conference.

7 Derrida focuses on this paradox when he describes justice as "an experience of the impossible," but insists that it exists as an aporia: "Law is an element of calculation, and it is just that there be law, but justice is incalculable, it requires us to calculate with the incalculable; and aporetic experiences are the experiences, as improbable as they are necessary, of justice, that is to say of moments in which the decision between just and unjust is never insured by a rule" (16). 
is located in a mythical, purifying violence outside of the state, Derrida, La Capra, and Agamben nevertheless seek alternative ways to act, politically speaking. In spite of their acute awareness of the paradoxes inherent in law and the modern state, they opt to confront themselves as actors on a political stage.

Echoing concerns debated in these essays, Carofiglio's novels treat the problem of how to act in the contemporary state. Though one might question the rebelliousness of a child who rejects the police profession to become an attorney, Guerrieri establishes himself in an oppositional position vis-à-vis a certain kind of law. Deeply committed to justice, but uncertain about what justice is or whether the system of law is the place in which to seek it, he navigates his career with considerable philosophical concern. $\mathrm{He}$ is a lawyer in order not to be a sheriff, in order not to occupy the traditional post of the fearless detective hero at the center of a crime storyin short, to evade the most troubling implications of collaborating in semilegal violence. Police, according both to Benjamin and to Derrida's reading of Benjamin, occupy the unenviable position of exerting law-establishing and law-preserving violence in a dark gray zone that is at the frontier between the two. Derrida explains Benjamin's account of this abstract role: "Where there are police, which is to say everywhere and even here, we can no longer discern between two types of violence, conserving and founding, and that is the ignoble, ignominious, disgusting ambiguity" (Derrida 43). When Guerrieri rejects the totalizing violence of the police force, he instead attempts to negotiate an acceptable position within the gray zone, working on behalf of the marginalized and seeking justice for the violence committed against them. But he never experiences his work as wholly satisfying, for in spite of the fact that he has chosen a less physical role as a representative of the law, violence erupts in his practice. The English-language concept of enforcing the law, Derrida suggests, reminds us "that there is no such thing as law (droit) that doesn't imply in itself, a priori, in the analytic structure of its concept, the possibility of being 'enforced,' applied by force" (6, emphasis in original). ${ }^{8}$ Reminiscing about the idealistic beginnings of his career, Guerrieri laughs bitterly, "Come faceva quella canzone di De Gregori? Cercavi giustizia, incontrasti la legge" (Ragionevoli 140). The difficulty is that, as Derrida aptly points out, "it turns out that droit claims to exercise itself in the name of justice and that justice is

8 While the word "enforce" has particular resonance in English, Derrida points out that in French, the concept of "force of law" exists (6); in Italian, the notion of "forza di legge" also bears out this interpretation. 
required to establish itself in the name of a law that must be 'enforced"' (22). Guerrieri constantly struggles with the contradictions born of this conflict.

As a result of this tension, we often find Guerrieri vehemently protecting his clients from the application of the law, rather than directly using it to protect them. In Testimone inconsapevole, his client is a young immigrant from Senegal wrongfully accused of having violently murdered a young boy and tossed him in a well; Guerrieri takes the part of the defence, seeking simply to demonstrate that his client is not guilty, at least not beyond a reasonable doubt. In Ragionevoli dubbi, he fights to absolve a man claiming to be unjustly imprisoned for drug trafficking, perhaps victim of a trap set by the lawyer originally supposed to represent him. Even when he represents the prosecution, as in Ad occhi chiusi, Guerrieri also finds himself in an oppositional position: this time he represents a young woman brutally abused by her boyfriend, who happens to be the son of the president of a division of the court of appeals. The father is widely reputed to be corrupt, and essentially untouchable. Guerrieri's decision to represent the woman constitutes an effort to stop the violence against her, but also a refusal to accept an extreme violence within the system. His determination is voiced, in his head, with vehement resolve: "Fanculo a Scianatico. Padre e figlio. Fanculo a tutti e due. Adesso vediamo, se non ti può succedere proprio niente, stronzo" (Occhi 38). With ironic, angry determination, Guerrieri attempts to combat the violence of the crime with a non-violent strategy in court.

\section{Professional Pathologies}

Carofiglio's Bari is a place where the illness of the entire Italian social body is evident. In Testimone inconsapevole, Guerrieri's client, a Senegalese vendor named Abdou Thiam, is clearly the victim of racism and xenophobia, as Guerrieri's skilful cross-examinations demonstrate. In Ad occhi chiusi, the attorney squares off against a man known to be an "ex picchiatore fascista, giocatore di poker. E cocainomane;" the man's father, on the other hand, is one of the most powerful men in the city, and also one of the most corrupt (Occhi 36). In Ragionevoli dubbi, Guerrieri's client was himself a "picchiatore fascista" during the years of student protests and the anni di piombo: "Si raccontava di rapine a mano armata [...]. Di campi paramilitari [...]. Di cosiddette feste ariane in ville lussuose della periferia. Soprattutto si diceva che Raybàn avesse fatto parte della squadraccia che aveva assassinato a coltellate un ragazzo di diciotto anni comunista e poliomielitico" (Ragionevoli 21). Guerrieri exists in an Italy terrified of its 
future as a destination for immigrants, haunted by its violent past and by the disappointments of its radical movements, and despoiled by corruption that runs through the system that is supposed to exercise justice.

This sickness is transmuted to Guerrieri's physical body. His discomfort with enforcing the law is figured as a pathology, as if he were allergic to the implications of fully serving the system. At the beginning of Testimone inconsapevole, Guerrieri begins to experience panic attacks; the first of these, significantly, occurs in his office elevator while returning from court. Subsequent to the first onset of panic, the fear that another terrifying wave might overtake him-in particular in the courtroom-prevents him from entering an elevator, causes him to suffer from insomnia, occasionally finds him fighting back tears, and requires him to spend long nights drinking, smoking, and watching television. An attorney friend with whom he discusses professional concerns also confesses to physical reactions to his career: "Quando ho cominciato mi sentivo come un angelo vendicatore. Adesso - potresti crederci? - ogni volta che devo arrestare qualcuno ho la nausea”" (Ragionevoli 140). Sartrean existential nausea assails the forty-year-old attorneys, causing them to question the validity of a profession that in more idealistic days they thought was the means to "fare giustizia" (140). Like his friend, Guerrieri is "sempre più a disagio con questo lavoro" (140).

Rather than take medication for his anxiety, however, Guerrieri boxes to ease his stress, a relief mechanism that, in recognizing the violence of the law, attempts to harness and redirect it. Boxing, "Una delle mie nevrosi'” according to the attorney (Ragionevoli 152), is another remnant from childhood, a sport his grandfather introduced him to when he came home from school with a face swollen from blows received from "un tipo più grande - e più cattivo - di me" (Testimone 33). While contemplating the time in his life spent boxing, Guerrieri realizes that "era stata una delle poche cose reali della mia vita. L'odore del cuoio dei guantoni, le botte darle e prenderle - la doccia calda dopo, quando ti accorgevi che per due ore nella tua testa non era passato un solo pensiero" (Testimone 34-5). Within the structured context of the ring, conditioning includes an agreement both to deliver and receive blows. Guerrieri's history as a boxer, first as a welter weight and then as a middle weight, catalogues the sportsmanlike levelling of physical ability that ensures that power is carefully managed to ensure fair matches. His recollection of the bells that signal the end of a match similarly indicates the temporal limitations on sporting events, which ensure that violence is delimited and can be halted. When Guerrieri becomes an attorney, he leaves aside sparring in the ring in favour of hit- 
ting a punching bag at home, and so boxing is practiced in an intensely personal, introspective space in which to sublimate the violence, and the injustice, of enforcing the law.

Guerrieri is not the only character in Carofiglio's novels to take advantage of the therapeutic powers of recreational violence. Margherita, whom he meets in the first novel and with whom he has a relationship in the second, has a black belt in aikido. A recovering alcoholic, she practices her sport in order to combat a pathological desire to drink. Suor Claudia, a central figure in the second, is a master of the martial art Wing Tsun. As a child, her father molested her, and she killed him before he could begin to abuse her younger sister in the same way; she took up Wing Tsun after she was released from a reformatory. For Margherita, Suor Claudia, and Guerrieri, skills in physical combat accompany the need to avoid violence to self, and also to sublimate a desire to do violence to others. The clearly delimited rules of boxing, aikido, and Wing Tsun-rules which determine the type of force used, the willingness of the opponent, the duration of a match-serve as checks that guarantee the nature and the appropriateness of the violence. Such checks do not, of course, exist in the world at large.

As a result of their athletic passion, the protagonists in Carofiglio's novels are routinely shapely, muscular, and lithe, while their antagonists are often massive, overweight, and out of shape. However, unlike a detective who might use his physical prowess to chase down a criminal, Guerrieri's physical fitness corresponds to the need to use recreational sparring as a means to sublimate the violence of the law itself. At one point, satisfied that he has done a good job for his clients, Guerrieri decides he does not need to train and explains, "non avevo neanche il senso di colpa, che di solito mi spingeva a fare a pugni con il sacco" (Occhi 61). More frequently, however, the attorney must turn to the punching bag to help diffuse or deflect the violence of his profession. "'Io cerco di scaricare l'aggressività facendo a pugni'” he explains to Suor Claudia (Occhi 79). Guerrieri learned to box as a boy in order to be able to defend himself against the bigger and the badder in the world, but as an adult, his skills instead sustain a courtroom strategy of meditative non-resistance.

This approach is illustrated in a fable that Suor Claudia recounts, her favourite about a martial art, the legend of the origins of ju-jitsu. A Japanese doctor, she explains, spent years studying means of combat. He was dissatisfied at the idea that force, the quality of arms, or other ignoble means usually prevailed in a fight. No matter how well-prepared a student of the martial arts might be, he may still encounter a stronger, better armed, or more cunning opponent. On a snowy day, the doctor observed 
weeping willows that, under the weight of an extraordinary snowfall, bent their gentle bows and let the snow fall to the ground: "Vedendo quella scena il medico provò un improvviso senso di esultanza e si rese conto di essere giunto alla fine della sua ricerca. Il segreto del combattimento era nella non-resistenza. [...] Ju-jutsu significa: arte della cedevolezza" (141). "Cedevolezza," or a willingness to yield, is the secret to the martial art, and provides an initial key to understanding Guerrieri's legal strategy. The technique of capitulation, which can also be understood as a strategy of deflection, parallels the attorney's invocation of the power of the law in the weakest terms possible: he uses it to diminish, rather than to establish, certainty. Guerrieri becomes a defensive warrior whose resistance off the matt or out of the ring rests in the power of inaction. In each novel, his re-direction of violence, as he refracts it into an insentient object, is also metaphorically his courtroom strategy.

\section{Rhetoric and the Art of Nonviolence}

Guerrieri attempts to negotiate a path of nonviolence for his clients, where nonviolence is understood, as Benjamin suggests, as "the omission of an action, or service" (281). Like a master of ju-jitsu, in the best circumstances he coaxes the law to cede to a non-violent solution, to withhold its powers to convict and to condemn. In Testimone inconsapevole and in Ragionevoli $d u b b i$, his clients are absolved; the law opts not to convict, and thus omits judgment, generally on the basis of insufficient evidence. This path of rupture constitutes a form of weak thought as Gianni Vattimo conceives it, as Guerrieri defends his clients against transcendent interpretations that would allow the absolutist force of the law to be brought to bear against them. ${ }^{9}$

As for any defence attorney, his words are used not to assert one truth, but rather to destabilize another. Guerrieri's strategies in the courtroom most often seek to demonstrate things that his interlocutors do not know-people they cannot recognize, things they do not remember, places they have not visited. On a number of occasions in the case defending Abdou Thiam, Guerrieri reminds the court of a well-known fact: "Lasciatemi ripetere questo concetto: l'imputato non deve provare niente.

9 In The End of Modernity, Vattimo describes weak thought as a form of philosophical nihilism that "leads to a weakening of the cogent force of 'reality" (27). In so doing, it opens the realm of possibility "to make possible all the other possibilities that constitute existence (27). Guerrieri's defensive strategy, which attempts to dislodge the narratives that apparently incriminate his clients, seeks to open other possibilities for them. 
È l'accusa che deve provare, al di là di ogni ragionevole dubbio, la responsabilità dell'imputato. Vi prego di ricordarlo in ogni momento di questo processo" (167). These familiar words, which describe a central tenet of legal procedure, draw attention to the philosophical core of Guerrieri's practice. His position is one of non-action, a position carefully barricaded within the simple need to not-know. When Testimone inconsapevole closes, we have no idea who has actually violently murdered the young boy. As Guerrieri explains to a friend who inquires about his client's innocence, "In un certo senso non è un problema mio. Ci tocca difenderli meglio che possiamo, siano innocenti o colpevoli. La verità, se esiste, la devono trovare i giudici" (181). Although the friend bursts out laughing and mocks Guerrieri for his formality, and although we know that he does indeed believe that Thiam has been wrongfully accused of murder, this lateral approach to justice is the one he most frequently takes. Instead of offering retributive satisfaction, the novel concludes with the gratifyingly just absolution of a presumably innocent man.

The work of disproving strong truths is inherent in the role of the attorney, a role based not in a search for certainty or an active investigation, but primarily in language, language enunciated in the courtroom. Language, potentially a "sphere of human agreement," according to Benjamin, is a realm of possible nonviolence (289). ${ }^{10}$ In each novel, a significant portion of the narrative takes place in the courtroom, where aside from limited descriptions of people standing up, sitting down, and casting glances one way or the other, the great majority of the text is occupied by direct and indirect discourse as the attorneys and judges exchange versions of their stories and question witnesses. Guerrieri is particularly attentive to his arguments as stories, a strategy that aligns with legal scholarship suggesting that storytelling holds particular power for marginalized groups. In an introductory chapter to an anthology titled Law's Stories, Paul Gewirtz explains this trend in legal studies: "Telling stories (rather than simply making arguments), it is said, has a distinctive power to challenge and unsettle the legal status quo, because stories give uniquely vivid representation to particular voices, perspectives, and experiences of victimization

10 By virtue of its civic nature, the courtroom is not a space that can be equated with the "conference," ("Unterredung," which Derrida translates as "dialogue"; 49) a discursive practice that Benjamin hypothesizes might be a private-sector corrective to the more violent public sphere. Nevertheless, the courtroom does become a space in which discourse, both direct and indirect, is the primary modus operandi, and where Guerrieri's careful use of language functions to free his clients. 
traditionally left out of legal scholarship and ignored when shaping legal rules" (5). These subjective stories, these shifting narratives that people assert as their distinct realities, vie for dominance in the world of the courtroom, where often someone's freedom hangs in the balance. Guerrieri attempts to take control of these narratives in order to ensure that the most gentle (and often the most subjective) version is that which emerges. For example, in the case that Guerrieri and assistant public prosecutor Alessandra Mantovani prosecute on behalf of the delicate Marina, the corpulent, aggressive defence attorney Dellisanti repeatedly raises objections to the very existence of the trial proceedings: "Questo era un fascicolo che non doveva arrivare a dibattimento. Doveva finire molto prima con una bella archiviazione" (Occhi 66). Part of the courtroom fight, then, is one that allows a silent circumstance (domestic abuse), which stands for a greater silence (the frequent silence of one partner abused by another), to find a voice. Language is thus already a form of justice, as it recognizes and enunciates the silent suffering of a victim.

Using words to protect citizens, Guerrieri's defensive strategy also leads him to erect barriers made of language. In Testimone inconsapevole, for example, as part of his defence of Abdou Thiam, Guerrieri makes a trip to the law library to consult a dictionary. The definition of "verosimile" helps him to argue his position:

'Verosimile, dice il vocabolario della lingua italiana Zingarelli, è quello che sembra vero e che, quindi, è credibile.

'Sembra vero e quindi è credibile.

'Sempre nello Zingarelli leggiamo la definizione di vero. Vero è ciò che si è effettivamente verificato, che è pienamente conforme alla realtà oggettiva. Alla voce vero troviamo, fra le altre, la locuzione: sembrare vero. Lo Zingarelli spiega che questa espressione - sembrare vero - si usa a proposito di cosa artificiale che imita perfettamente la realtà. (278-279)

While the prosecuting attorney at this point accuses Guerrieri of sophistry, he goes on to demonstrate that the case against his client is constructed in the world of verisimilitude, of fiction and artifice, rather than in reality. It appears true, yet there is no way to confirm that it actually is. By chipping away at a story presented as certain, Guerrieri demonstrates that punishing a verisimilar criminal with a real term of incarceration would be an affront to justice. In this case, a real body would be subject to the effects of an abstract, absolute concept. Again, he makes this argument with reference to language: "Le sentenze [...] non si scrivono — non si possono scrivere - al modo condizionale. Si scrivono all'indicativo, affermando certezze. Certezze" (Testimone 297). While well aware that judicial sen- 
tences are not actually based on "certainties" but rather on stories that convince beyond a reasonable doubt, Guerrieri uses these words to ensure Abdou Thiam's acquittal and eventual freedom.

Guerrieri's strategic use of language may aspire to be gentle, yet time after time Carofiglio portrays his attorney capitulating to more forceful passions. Storytelling can help to achieve a desirable legal end, but words, too, risk violence. Ultimately, Carofiglio emphasizes that Guerrieri also manipulates language to his advantage, and forcibly shapes outcomes in the courtroom. This becomes explicit in a seemingly autobiographical detail, when the attorney confesses his desire to become a writer. Late one night in his favourite bookstore, the owner shows him a book titled $L a$ manomissione delle parole: appunti per un seminario sulla scrittura. Guerrieri reads an excerpt suggesting that the words that we use are often stripped of their significance by overuse, and in particular, by unwitting use. In order to tell stories, then, words must be regenerated: broken to bits and reconstructed. This is the act of "manomissione":

La parola manomissione ha due significati, in apparenza molto diversi. Nel primo significato essa è sinonimo di alterazione, violazione, danneggiamento. Nel secondo, che discende direttamente dall'antico diritto romano (manomissione era la ceremonia con cui uno schiavo veniva liberato), essa è sinonimo di liberazione, riscatto, emancipazione.

La manomissione delle parole include entrambi questi significati. Noi facciamo a pezzi le parole (le manomettiamo, nel senso di alterarle, violarle) e poi le rimontiamo (le manomettiamo nel senso di liberarle dai vincoli delle convenzioni verbali e dei non significati). (Ragionevoli 128-129, italics in text)

According to this definition, the task of a writer, like that of an attorney, occupies a space characterized both by freedom and by violence. In the case of the writer, the violence is enacted specifically in order to free the words - an apparently necessary step towards a new sphere of language.

Although language is the space that brings Carofiglio closest to Guerrieri, author and protagonist cannot, of course, be conflated. Mark Chu points out that Guerrieri, a fully-developed and self-reflective character, is constructed in such a way that readers must evaluate his behaviours critically. ${ }^{11}$ Additionally, Chu observes that at times Carofiglio sets himself in an antagonistic relationship with his protagonist. For example, Guerrieri

${ }^{11}$ Chu argues that "while the character of Guerrieri sometimes displays prejudice and sexist attitudes, the author sometimes introduces an element of critique into the representation, with varying degrees of success" ("Crime and the South"). 
not infrequently uses courtroom strategies that Carofiglio specifically warns against in L'arte del dubbio, betraying a tendency to allow his passions to get the better of him. ${ }^{12}$ Periodically, then, he seems to fail at the art of nonviolence. As Guerrieri and Mantovani work to accuse Scianatico of abusing Marina, both at times erupt in violent language in the courtroom. Irked by the arrogantly aggressive attitude of the defence attorney, Guerrieri takes issue with a piece of evidence that has been added to the trial records (and with the unkind language Dellisanti uses to label the woman a "squilibrata" [Occhi 121]). Defence attorney Dellisanti, red in the face, "Urlò che lui non accettava lezioni di procedura" and yells other things too, but Guerrieri admits, "non le sentii perché anch'io alzai la voce, e in breve l'udienza si trasformò in quello che si dice una indegna gazzarra" (126). Later in the same trial, Mantovani objects to an intimidating line of questioning Dellisanti takes with Marina, and he bristles at her objections. Her response is "breve, rapida e micidiale come una pugnalata" as she intervenes: "'Stia attento lei, avvocato; stia attento $a$ lei'. Lo disse con un tono che faceva gelare il sangue. C'era una violenza, in quelle parole sibilate, che lasciò esterrefatti tutti i presenti, me incluso" (174). The fierce nature of Alessandra's words, words compared to a physical blow, once again emphasizes the violence of the law.

Like writing, Guerrieri's justice by means of non-action functions at times, but it also serves to demonstrate the "problematic nature of law itself" (Benjamin 287). Violence interpolates itself into Guerrieri's court cases, and into his life, in spite of his best efforts. In Ad occhi chiusi, while prosecuting the wealthy, privileged son of another member of the legal system, he performs an assault on the system itself. The defence's case rests on the argument that the woman accusing Scianatico of abuse, who has suffered anorexia nervosa in the past and seen a psychiatrist, is thus an unreliable witness. In the course of the trial, rather than taking a positive position, Guerrieri makes some progress in demonstrating the corresponding unreliability of the defendant-rather than proving the offense to his client, he

12 In Testimone inconsapevole, Carofiglio playfully acknowledges this divergence between non-fictional theory and fictional novel. As he proceeds with a daring but risky move in the trial, Guerrieri admits, "I manuali per avvocati direbbero che questo è un modo sbagliato di procedere. [...] Volevo vederli fare un maledetto processo, quei signori che scrivono i manuali. Voglio vederli in mezzo al rumore, alla sporcizia, al sangue, alla merda, di un processo vero. E voglio vederli applicare le loro teorie" (177). Although disregarding "advice" from author Carofiglio, Guerrieri defends his actions in terms that once again focus the issue of violence and the law. 
opts to demonstrate the weakness of the position of the defence. Whether this strategy had the potential to convince the courts, however, is uncertain, because the defendant in the meantime beats his ex-girlfriend to death, suspending her complaint against him. Scianatico kills Marina immediately after one of Guerrieri's successful interrogations in which he brings the defendant's character in question. And so Guerrieri muses:

Ho ripensato spesso a quell'udienza, e a quello che successe dopo. Mi sono chiesto spesso se le cose potevano andare diversamente, e quanto siano dipese da me, dal mio comportamento nel processo, dal modo in cui interrogai Scianatico.

Non ho mai trovato una vera risposta, e probabilmente è meglio così. (221)

Unlike Testimone inconsapevole, then, in which non-proof spurs the non-action of not-convicting Abdou Thiam, an outcome guaranteed by the right kind of dialogue, Ad occhi chiusi closes with tragic action, action precipitated by the inherent violence of the law.

This, in theory, is part of ju-jitsu as well, and is the contradiction at the heart of Guerrieri's strategy. When Suor Claudia recounts the story of the origins of the martial art and Guido considers sceptically her ability to yield to others, she explains:

'Ovviamente bisogna intendersi su cosa significhi cedevolezza. Significa resistere fino ad un certo punto, e poi sapere esattamente in quale momento cedere, e sviare la forza dell'avversario, che alla fine si ritorce contro di lui. Il segreto dovrebbe essere nel saper trovare il punto di equilibrio fra resistenza e cedevolezza; cedevolezza e resistenza; debolezza e forza.' (Occhi 142)

So Guerrieri sometimes side-steps violent action, but at other times he fights, ever seeking the balance between forceful resistance and pliability. In Testimone inconsapevole, threatened by a couple of thugs sent to discourage him from prosecuting a case against illegal dog fighting rings, Guerrieri must defend himself. His first act is defensive: he blocks a punch with his left hand. But "quasi contemporaneamente lo colpii con un destro al viso" (97). Guerrieri proceeds to knock down Thug Number Two, although he does resist the impulse to kick his assailant in the face: "O di offenderlo; o di offenderli tutti e due" (98). Here, the attorney controls the desire to apply excessive force, using only the aggression necessary to ensure that he can continue to prosecute the case, and thus help to halt a cruel practice. When in Ad occhi chiusi he has to stop a crazed Suor Claudia from killing Scianatico, who has just killed Marina, the knock-out punch 
he employs is portrayed as an almost clinical means of immobilizing her, "come un'anestesia" (231). An anaesthetic, used in medicine to render a subject unconscious or to make her immune to pain, constitutes another form of weak action, a numbing and an undoing rather than a deliberate infliction of harm. In both cases, when Guerrieri uses his physical skills against others, violence is used to combat and prevent further violence. Strategy, as Guido knows well, is "l'arte del paradosso" (Occhi 142), and regardless of his desire to tread a path of nonviolence and of justice, at times this paradox requires him to betray his principles in order to (pragmatically) act his conscience.

\section{Paradoxical Positions}

One of Guerrieri's most complicated crises of conscience occurs in Ragionevoli dubbi, when a telegram arrives announcing that Fabio Paolicelli has named him his defence attorney. The name sounds familiar to Guerrieri, and when he meets his client in prison, he immediately recognizes him: Paolicelli is also known as Fabio Raybàn, and was allegedly, as noted above, part of a squad of Fascist thugs who killed a young communist in Bari in the 1970s. But Raybàn has a more personal connection to Guerrieri, and a more hostile one. Days after the assassination, in a Bari rocked by violence, a young Guerrieri and his friend are assaulted by a group of older, aggressive boys, one of whom wears Ray-ban sunglasses. Accusing Guerrieri of being a compagno, the gang begins to kick, punch, and slap him, until someone finally arrives and sends them away. "Un giorno ve la farò pagare" (24), Guerrieri promises himself. Thus when years later Paolicelli asks Guerrieri to defend him against charges of drug trafficking, the attorney has a chance for revenge: "Capii molto chiaramente che volevo essere il suo giudice- $\mathrm{e}$ forse anche il suo boia-piuttosto che il suo avvocato. Volevo regolare un vecchissimo conto" (27). Guerrieri's grouping of the roles of judge, executioner, and lawyer in the course of this short revenge fantasy reveal a number of important things. Firstly, through his role as an attorney, in the right circumstances he has the possibility of being all of these things simultaneously: through an ineffective or outright antagonistic representation of his client, Guerrieri could indeed deliver Raybàn back into the bowels of the prison system for a very long time, acting effectively as judge and a sort of executioner. Secondly, we learn that Raybàn is imprisoned because of the criminally fraudulent work of his first attorney, who had performed precisely those roles_- "defending," judging, and leaving his client to suffer. Potentially guilty of many things, he is most 
likely innocent of the crime for which he has been locked away.

Most importantly, however, Guerrieri attempts to transcend his own past; he opts to dedicate himself to the case and succeeds in securing Raybàn's acquittal and release. Judging Raybàn/Paolicelli for the events of thirty years ago is not his current job, nor is it the role of the penal system. Guerrieri neatly slips a man with a shady past out of prison, insisting that the law must not make inappropriate incursions into the life of its citizens. In spite of his recognition of the slippage between attorney, judge, and executioner, Guerrieri endeavours to maintain the integrity of his role by learning to cedere, to give in, to weaken his relationship to his past and his memory in order to serve justice and truth, though he does not fully believe in the latter. He exchanges his revenge narrative and the circular logic of "an eye for an eye" for another, less decisive, non-violent story. When the court retires to deliberate, his mind is filled not with conviction but with questions: "I fatti degli ultimi quattro mesi erano veramente accaduti? [...] In base a cosa possiamo dire con certezza che una immagine nella nostra testa è il risultato di una percezione o di un atto di immaginazione? Cosa distingue davvero certi sogni da certi ricordi?" (287). This tenuous belief in reality, coupled with Guerrieri's conviction that sentences are written as certainties and that incarceration is incontestably absolute, leaves us to conclude that this fictional lawyer can only successfully perform the role of defence attorney, can only help to acquit, to forgive: this is the path of cedevolezza.

A testimone consapevole of the rocky path he treads, in the Guerrieri novels Carofiglio performs a critique of the violence of his own position, and like Benjamin, seeks to see, through this assessment, the relationship of violence to law and justice (Benjamin 277). For Benjamin, however, this reflection led to a dramatically mystical conclusion to his essay. Towards the end of "Critique of Violence," after a political analysis of the mechanisms of power and their ties to violence, Benjamin begins to speak of a messianic, pure violence, which would have no relation to the law and which would therefore somehow create a rupture in the system, allowing for a position outside the vicious circle. This "divine" violence, for Benjamin, exists in opposition to the "mythical" or "state" violence and is "law-destroying," rather than "lawmaking" or "law-preserving." The extreme solution to the philosophical impasse Benjamin reached is, not surprisingly, a turn which preoccupies readers; yet Benjamin's messianic solution seems to reflect a temptation that lurks at the root of many discussions of justice- a desire to break free of the paradoxical nature of law.

As I noted before, when confronting the challenging final section of "Critique of Violence," many critics agree that at the heart of Benjamin's 
article there lies an irreconcilable contradiction that, however problematic, does reflect the knotty nature of violence in the law. For Derrida, this is an aporia that exists at the heart of justice; for Agamben, it is evidence of the constant tension between juridical order and anomie, between power and pure violence. The question of anomie is a particularly significant one in Carofiglio's novels. For Agamben, anomie is a "zone" in which "violence without any juridical form acts," a state that reflects the sense of the term as a kind of breakdown of societal forms (59). Anomie, however, also has a more private definition; it can be defined as "personal unrest, alienation, and uncertainty that comes from lack of focus or ideals," a state proper to individuals, rather than societies ("anomie"). It can thus either be general - as the state of the sick body politic — or specific — as the state of an individual attorney from Bari who suffers panic attacks and has few friends. Guerrieri, suffering from anomie, risks being paralyzed, as we find him at the opening of the trilogy:

C'erano diverse persone la cui libertà dipendeva dal mio lavoro e dalla mia concentrazione. Suppongo che avrebbero trovato interessante scoprire che trascorrevo i pomeriggi sfogliando distrattamente i loro fascicoli, che di loro e del contenuto di quei fascicoli non poteva importarmi meno, che andavo in udienza del tutto impreparato, che l'esito dei processi era affidato praticamente al caso e che, insomma, il loro destino era nelle mani di un irresponsabile psichicamente disturbato. (26)

Guerrieri's exceedingly problematic feeling of resignation, as has been evident, does not persist throughout the novels. But given his concern regarding the paradoxical nature of the relationship between violence and the law, one might wonder why it does not. How can he be so sceptical and yet so diligent at the same time?

The answer lies somewhere between the exigency to critique and the need to act, or between the interpretive "cosa significa?" and the technical "come si fa?" 13 In fact, in his debate with Derrida about "Critique of Violence," La Capra usefully notes that Benjamin's final, abstract distinction between "mythical" or "state" violence and "divine" violence is problematic, politically speaking, because it leads Benjamin "to lump all states together independent of their constitutions or political and economic

13 In L'arte del dubbio, Carofiglio explains the need to concentrate on strategy by suggesting the, "La tecnica offre in primo luogo risposte alla domanda 'come si fa?': e solo dopo questo passaggio coonsente eventualmente la speculazione, l'individuazione di principi di natura teorica, di risposte alla domanda 'cosa significa?' (Arte 16) 
regimes. All are violent in a 'rotten' manner" (1071). La Capra warns that "Benjamin's mode of address may seem acceptable if one believes one may justifiably subvert or even destroy the state, ignore consequences, and leave one's objective a blank or an act of faith" (1071). Somehow, a contemporary conscientious relationship to the law, which cannot embrace Benjamin's mystical solution, must nevertheless recognize the inherent contradictions that arise at its founding-that thorny difference between justice and the exercise of justice. Carofiglio's reluctant, sometimes panic-stricken, nonsheriff lawyer, exists in the author's awkward knowledge of this link between power and pure violence, and in the discomfort of wanting to protect people from the law while knowing that there is no good position from which to do so. But although Guerrieri frequently bumbles through the legal system, encountering its limits, Carofiglio continues to write novels that focus on these crises, recounting them to popular audiences.

As Derrida and La Capra meditate on the enduring significance of "Critique of Violence," they opt not so much to disagree as to focus attention on different aspects of Benjamin's essay. Derrida suspects that justice is a non-road, an aporia, and that it is impossible to experience. Law, an element of calculation, might be held accountable when a courtroom decision comes out well, but law is not justice: "justice is incalculable" (16). He identifies a fundamental difference between justice, which he says is "infinite, incalculable, rebellious to rule and foreign to symmetry, heterogeneous and heterotropic" [sic]; and the exercise of justice, which is legitimate, stable, "calculable, a system of regulated and coded prescriptions" (22). Impossible but existent, justice forces us to wonder how to "reconcile the act of justice that must always concern singularity, individuals, irreplaceable groups and lives, the other or myself as other, in a unique situation" with any kind of rule of law (17). Building on Derrida's reading, La Capra instead highlights the problem the essay creates: a problem of "the relation between ignorance and the problem of decisive action" (1078) in short, the problem of what to $d o$, given this problematic reading of justice, violence, and the law.

In defending Abdou Thiam, Guerrieri makes a distinction between justice and summary justice, "giustizia sommaria," when appealing to the jurors, saying that they must leave aside temporary solutions. By implication, he suggests that they must instead call on an eternal concept of justice, one not bounded by the temporary need to inflict violence, to punish. But this eternal concept of justice, for Guerrieri, constitutes one more reason not to apply such a concept. Jurors, he insists, must apply the criteria of certainty before condemning the accused to a life sentence; they must 
be able to say that every other hypothesis is implausible, and have proof that the proposed narrative is the only one possible. "Certezze," he reminds them time after time. "Certezze." These arguments extend past legal practice and its burden of proof beyond a reasonable doubt. In spite of the attorney-protagonist's insistence on truth, Carofiglio's narratives remind us of the near-impossibility of certainty, and thus in order to serve justice, infinite, heterogeneous justice, his novels prefer to depict the weakest possible exercise of justice (almost a non-exercise) - the decision not to condemn.

By writing popular novels about Guerrieri, Carofiglio maintains his commitment to action and to justice, even as he muses about its limitations and the potential rottenness of the system. Guerrieri combats anomie in Ragionevoli dubbi when he asks the court, "che cosa è giusto fare? Non in astratto, nel rispetto del metodo e della teoria, ma in concreto, in questo caso, per la vita di quest'uomo" (286). Together with the contemporary scholars, Carofiglio demonstrates that it is imperative to transcend the paradoxes and find a way to act. Derrida hypothesizes: "That justice exceeds law and calculation, that the unpresentable exceeds the determinable cannot and should not serve as an alibi for staying out of juridico-political battles" (28). And La Capra focuses attention on the all-important political question, "What is to be done?'-one political question if not the political question par excellence-as crucial to Benjamin's text" (1075). While Guerrieri is tentatively happy at the outcome of some of his courtroom cases, Carofiglio makes clear that philosophical doubts remain regarding their absolute value. "[A] volte," Guerrieri muses, "quello che facevo poteva addirittura avere a che fare con la giustizia. Qualunque cosa significhi la parola" (Ragionevoli dubbi 231). His sardonic "sometimes" and "something to do with" qualify the nature of his legal interventions as tenuous, occasional, uncertain-weak actions that necessarily characterize the life of someone so unsure about the reasons for engaging in an institution that may be irretrievably tainted.

But the final means of countering anomie constitutes a distancing, a play which takes the narrative momentarily away from the question of violence and the law. As Ad occhi chiusi closes, we find Guerrieri skydiving, suspended in the air with his arms out, recalling his happiness as a child; he is literally removed from the world he attempts to serve. Ragionevoli dubbi ends in a similarly liminal space. Guerrieri jokingly affirms his friendship with police inspector Tancredi with a reference to Casablanca (“'Louis, credo che questo sia l'inizio di una bella amicizia”), and the two wander off into a hazy border space at the edge of Bari, "Là dove finiscono le case, i ristoranti, le insegne, e rimangono solo le luci cordiali ed enig- 
matiche dei lampioni di ghisa" (299). The non-space of the skydive and the non-space at the edges of Bari establish another means to non-violence, a way in which the novels can act out a playful relationship with a larger, somewhat troubling portrait of society.

These two endings stage a temporary suspension of their focus on the law, pulling away in significant fashion from the courts into the more personal world of play. As such, they open an awareness of Guerrieri's, but more emphatically of Carofiglio's, tendency to "studious play"- a possibility that Agamben sees beyond the impasse that blocks law in a place of violence-as a possible means to open a "passage toward justice" (64). Reflecting on another essay by Benjamin that examines a short story by Kafka, Agamben suggests that the law, "no longer practiced, but studiedis not justice, but only the gate that leads to it. What opens a passage toward justice is not the erasure of law, but its deactivation and inactivity [inoperosità] - that is, another use of the law" (64). In this sense, Carofiglio's legal procedural novels, which many critics laud for things other than their representations of legal procedure, play with the law in a way that makes it useful for something entirely new and different. The focus on Guerrieri's passion for the martial arts, seen in this light, allows Carofiglio to connect play and the law in a studious fashion. The novels' conclusions outside of the courtroom cement the author's commitment to a place after the law-after the world, even - where such a rapport with the law is possible. As Guerrieri jumps from the plane, he enacts a new use of his body, discontinuous with all other experiences up to then. His joking but affectionate words for Tancredi, a police officer and thus someone that Guerrieri definitively refused to be, show a new ability to deactivate the violence of the idea of "police" by assigning it another use: friendship. At the end of the novels, then, Carofiglio sketches a fictional version of what Agamben, again discussing Benjamin, suggests one might achieve in studious play: a "state of the world in which the world appears as a good that absolutely cannot be appropriated or made juridical" (64).

In theorizing the potential theoretical benefits of "play," Agamben may fall prey to a form of utopianism. In her excellent (and generally positive) review of State of Exception, Margaret Kohn characterizes Agamben's hopes regarding "studious play" as "messianic," as "utopianism that provides little guidance for political action." She warns further that, "Agamben might do well to consider Hannah Arendt's warning that the belief in justice unmediated by law was one of the characteristics of totalitarianism," and suggests that the philosopher risks falling into a trap similar to the one that caught Benjamin at the end of "Critique of Violence" - that of hoping that 
politics can be liberated from "the law tied to violence and the demarcating project of sovereignty" ("Bare Life"). Carofiglio's fiction may nevertheless indicate one way in which "play" (in the form of literature) can comprise a form of political action separate from violence. At the very least, the novels are a forum in which to sound the problems of violence and the law.

\section{WAYNE STATE UNIVERSITY}

\section{WorKS CiTED}

Agamben, Giorgio. State of Exception. Trans. Kevin Attell. Chicago: University of Chicago Press, 2005.

“anomie." Merriam-Webster Online Dictionary. 2009. Merriam-Webster Online. 1

October 2009 http://www.merriam-webster.com/dictionary/anomie.

Barbolini, Roberto. "Guerrieri, l'avvocato a duello con Perry Mason.” Panorama (22 Feb. 2007): 150-151.

Benjamin, Walter. "Critique of Violence." In Reflections. Ed. Peter Demetz. Trans.

Edmund Jephcott. New York: Schocken Books, 1978, pp. 277-300.

Carofiglio, Gianrico. L'arte del dubbio. Palermo: Sellerio, 2007. Ad occhi chiusi. Palermo: Sellerio, 2003.

—. Il paradosso del poliziotto: dialogo. Rome: Nottetempo, 2009.

—. Ragionevoli dubbi. Palermo: Sellerio, 2006.

-. Testimone inconsapevole. Palermo: Sellerio, 2002.

Chu, Mark. "Crime and the South." In Italian Crime Fiction. Ed. Giuliana Pieri. Cardiff: University of Wales Press, forthcoming.

Derrida, Jacques. "Force of Law: The 'Mystical Foundation of Authority." In Deconstruction and the Possibility of Justice. Eds. Drucilla Cornell, Michel Rosenfeld, and David Gray Carlson. New York: Routledge, 1992, pp. 3-67.

Gewirtz, Paul. "Narrative and Rhetoric in the Law." In Law's Stories: Narrative and Rhetoric in the Law. Ed. Peter Brooks and Gewirtz. New Haven: Yale University Press, 1996, pp. 2-13.

Kohn, Margaret. "Bare Life and the Limits of the Law." Theory \& Event 9.2 (2006). http://muse.jhu.edu/journals/tae/v009/9.2kohn.html. Accessed 8 October 2009.

La Capra, Dominick. "Violence, Justice, and the Force of Law." Cardozo Law Review 11 (1990): 1065-1078.

Sciascia, Leonardo. Il cavaliere e la morte. Milan: Adelphi, 1988.

—. Il giorno della civetta. Milan: Adelphi, 1993.

—. Opere: 1971-1983. Ed. Claude Ambroise. Milan: Bompiani, 1989.

—. Una storia semplice. Milan: Adelphi, 1989.

Vattimo, Gianni. The End of Modernity. Trans. Jon R. Snyder. Baltimore: Johns Hopkins University Press, 1988. 